\title{
Permanent Health Education and psychosocial care: the experience of the Projeto Rede Sampa
}

\author{
Educação Permanente em Saúde e atenção psicossocial: a experiência \\ do Projeto Rede Sampa
}

Christiane Mery Costa $\mathbf{1}$, Claudia Regina de Moraes Abreu' $\mathbf{1}$, Paulo Amarante', Felipe Rangel de

Souza Machado 1

DOI: 10.1590/0103-1104202012726I

\begin{abstract}
This article reports on a training experience in mental health developed in the city of São Paulo between 2013 and 2016. Named Projeto Rede Sampa - Saúde Mental Paulistana, it was aimed at workers from different professional categories and different points of the Psychosocial Care Network, having been elaborated and executed using strategies that ensured the participation of the different actors in the construction of learning contents, the approach to the singularity of territorial networks and the registration of the training path of the classes. Based on the social constructionist methodology, we sought to discuss the relevance of dialogical interactions for the strengthening of networking and the importance of alignment with psychosocial care as an ethical model of care.
\end{abstract}

KEYWORDS Education, continuing. Psychosocial support systems. Health care (public health). Mental health.

RESUMO Este artigo relata uma experiência de formação em saúde mental desenvolvida no município de São Paulo entre os anos de 2013 e 2016. Denominado Projeto Rede Sampa - Saúde Mental Paulistana, direcionou-se a trabalhadores de diversas categorias profissionais e diferentes pontos da Rede de Atenção Psicossocial, tendo sido elaborado e executado utilizando estratégias que garantiram a participação dos distintos atores na construção de conteúdos de aprendizagem, a abordagem da singularidade das redes territoriais e o registro do percurso formativo das turmas. A partir da metodologia construcionista social, procurou-se discutir a relevância das interações dialógicas para o fortalecimento do trabalho em rede e a importância do alinhamento com a atenção psicossocial como modelo ético de cuidado.

PALAVRAS-CHAVE Educação continuada. Sistemas de apoio psicossocial. Atenção à saúde. Saúde mental. 


\section{Introduction}

Between progress made and setbacks in the field of public policies in Brazil since the institution of the Unified Health System (SUS), the mobilization of workers, users and family members around the psychiatric reform and the anti-asylum struggle have reaffirmed the adoption of the psychosocial care model, guided by an emancipatory ethics focused on welcoming the singular experience of the individuals' existence and based on investing in social practices capable of modifying the conceptions about the disease and reducing the social prejudice related to it, transforming life territories into places of care.

The establishment of the Psychosocial Care Network (Raps) by Ordinance No. 3,088/2011 institutes the diversification of care strategies for people with mental suffering or disorder, aiming to achieve comprehensiveness by expanding and articulating different points of care. The proposition of establishing assistance flows involving basic, psychosocial and hospital care (the latter encompassing urgency and emergency), as well as residence care strategies, dehospitalization and social inclusion, all this by means of work and culture, means that professionals can include the psychosocial paradigm in a list of references recognized and validated by them at all points in the network.

The training given to workers in processes of PermanentEducation in Health (EPS), as recommended by the National Policy for Permanent Education in Health (PNEPS), should consider experiences and perceptions of professionals as something capable to generate significant learning. In a model of the Health Care Networks (RAS), this can be a resource favoring dialogical movements and negotiation strategies among health agents with a view to establish solidary relationships, recognize and build formal and informal partnerships in the territories, create conditions for changes in the continuum of care, and validate new knowledge and learning.

In this article, we lean over the experience of the Sampa Network Project - Saúde Mental
Paulistana (PRS), which brought together the fields of mental health worker training, making it possible to engage Raps workers in psychosocial care and to address setbacks that can be foreseen when services are encouraged to rescue the asylum model.

Based on the assumptions of psychosocial care and EPS, in the year of 2013, the city of São Paulo established a partnership with the Ministry of Health (MS) Secretariat for Labor Management and Health Education (SGTES), seeking to promote qualification of SUS health professionals working at Raps. The PRS highlighted the possibility of there being collective construction of knowledge, bringing workers together and facilitating the creation of new sociability networks necessary for the functioning of the Raps.

This experience report is the result of research $^{2}$ that sought to understand the meaning of ongoing education for health professionals who participated in the project. The cut was made considering the actions developed between the years 2014 and 2016, encompassing short courses, with a 60-hour workload, in the semi-presence modality, with 32 hours of classroom activities and 28 hours of activities in the Virtual Learning Environment (AVA). The use of AVA included the elaboration of collective narratives as a course conclusion work, which aimed to present the interface between the content discussed and the work territory from the point of view of students/workers.

It is a qualitative research, with a hermeneutic approach and the use of social constructionist methodology which analyzed the interaction and the sharing of knowledge that occurred in the formative paths, and discussed the importance of dialogical interactions to improve the organization of the care network and the production of meaning in the validation of work practices. Focus groups and interviews were carried out with students, teachers and coordinators who participated in it. The research was authorized by the Research Ethics Committees of the training institution (CAAE: 91285818.9.0000.5241 - Opinion: 2.804.408) 
and by the Municipal Health Secretariat of São Paulo (CAAE: 91285818.9.3001.0086 - Opinion: 2.858.118).

\section{Outlining a project for training on networking}

In December 2012, in the transition from one municipal administration to the newly elected one, the Municipal Health Secretariat of São Paulo signed an agreement with the SGTES to hold workshops to update workers in the field of mental health, and this included the transfer of financial resources to be managed by the municipality.

As, at the time, the municipality had not structured an EPS project for the Raps, the strategic choice, in the sense of guaranteeing the receipt of funds, was to adhere to a project of the Ministry of Health still in the implementation phase and this basically involved holding three workshops for training workers for mental health care, which were as follows:

- Child and Adolescent Mental Health;

-Care in Crisis Situations in Mental Health;

- Update on mental health and networking: demands related to the consumption of alcohol and other drugs.

A large part of the training courses conceived by the Ministry of Health at the time had its planning carried out in a centralized manner and was prepared by content writers based on questions relevant to the entire national territory. Teachers, selected regionally, were given pedagogical training and access to teaching material to be used, and this was a format that was in opposition to the PNEPS pedagogical assumptions, which encourage a problem interpretation methodology in order to generate meaningful learning, and mediate a path that should put the practice of workers in analysis, thus stimulating critical reflection and the construction of new knowledge.

The group in charge of the agreement in the municipality understood the actions of the EPS as being strategic resources for the management and organization of health care, and that an upward, decentralized and transdisciplinary logic should be followed, as defined by Ceccim and Feuerwerker ${ }^{3}$. Therefore, in 2013, a new training plan was developed, expanding the scope of the project to now include short courses, with improvements and specializations in mental health aimed at professionals with different educational and training levels. Evaluations on the training process and production of thematic notebooks by health workers were also foreseen in the proposal called Projeto Rede Sampa - Saúde Mental Paulistana (PRS).

The objectives of the PRS were to qualify workers in the health care networks for mental health care, with a focus on: maintaining social and family bonds and minimizing psychological distress; integrating and articulating between sectors the various services for strengthening the Raps in the municipality; and promoting a networked care in the pursuit of a comprehensive health care for the population, based on the reorganization of work processes.

The starting point for the redefinition of the actions was to carry out a survey on the training needs in mental health as perceived by the workers located in the different points of the Raps with a set of tools for that purpose and the identification of themes considered relevant.

The task of transforming those needs into didactic-pedagogical content involves building theoretical and conceptual frameworks, developing content and defining learning methodologies. The focus of the PRS on strengthening the Raps aimed to transform the territorial organization into an element to be included in the debates among the workers in the classroom, having the teacher as a mediator of the discussions. It was important for the content, 
although present and innovative, to be permeable to new issues emerging from the encounter between teachers and students, allowing a constant re-signification of the problems and territorial potentialities.

The themes pointed out by the workers were grouped into four thematic areas, and the planning of the short courses took place with the creation of Groups of Trainers composed of coordinators and teachers from the same area, responsible for the elaboration (and re-elaboration) of the classes throughout the course (table 1). This strategy required routine group meetings and boosted important mutual support for strengthening teaching.

Table 1. Main characteristics of the work of the group of trainers

\begin{tabular}{|c|c|c|}
\hline Characteristics & Area coordinator & Teacher \\
\hline Mode of selection & Highly renowned. & Public tender. \\
\hline Necessary experience & $\begin{array}{l}\text { In the Academia and in course coor- } \\
\text { diation. }\end{array}$ & $\begin{array}{l}\text { Teaching and activity in the Psycho- } \\
\text { social Care Network. }\end{array}$ \\
\hline \multirow[t]{5}{*}{ Tasks } & $\begin{array}{l}\text { Elaborate course sylabus based on } \\
\text { the needs identified by the workers. } \\
\text { Point out the theoretical references } \\
\text { and bibliography. }\end{array}$ & Give classes. \\
\hline & $\begin{array}{l}\text { Participate in regional rounds of } \\
\text { discussion, discussing matters of the } \\
\text { different territories of work. }\end{array}$ & - \\
\hline & $\begin{array}{l}\text { Coordinate training meetings with } \\
\text { teachers, elaborating class plans. }\end{array}$ & $\begin{array}{l}\text { Participate in meetings with Area } \\
\text { Coordinators. }\end{array}$ \\
\hline & $\begin{array}{l}\text { Develop material for the Moodle } \\
\text { Platform and the triggering questions } \\
\text { for producing the Collective Narra- } \\
\text { tives text. }\end{array}$ & $\begin{array}{l}\text { Follow up and encourage the develop- } \\
\text { ment of activities in the Virtual Learn- } \\
\text { ing Environment. }\end{array}$ \\
\hline & $\begin{array}{l}\text { Monthly follow-up with teachers } \\
\text { making adjustments to the content } \\
\text { based on suggestions made by teach- } \\
\text { ers in general. }\end{array}$ & $\begin{array}{l}\text { Present to the group of trainers the } \\
\text { reflections regarding the contents } \\
\text { worked upon and their correlation } \\
\text { with the local territorial network, } \\
\text { colaborating to adjusting the syllabus } \\
\text { and the class plans. }\end{array}$ \\
\hline
\end{tabular}

According to Ceccim and Feuerwerker,

[...] formal knowledge must be implied with movements of self-analysis and self-management of the collectives of reality, given that it is the actors of the daily life who deserve to be the protagonists of the change in reality desired by the educational practices ${ }^{3(62)}$.
The various strategies adopted must, from this perspective, start from an understanding of theory and practice as inseparable elements.

Before the start of each course, 'rounds of regional conversations' - meetings between the area coordinator and the workers of the municipal macro-regions - were held in order to present the main approaches 
proposed for the courses and to be open to the territorial particularities of workers, the main social determinations of health and the ways of organizing services and network. The topics emerging from these circles were later incorporated into the course syllabus.

Once the actual courses began, the classes of students/workers were constituted in a heterogeneous way both in terms of education and training and in terms of insertion in work units. Depending on the regional assessment regarding the pertinence of activating the intersectoral networks, the participation of external health professionals - such as public defenders, guardianship counselors, social assistance and education professionals - was also made possible, in an exercise to expand the problematization of healthcare network.

It is a course in the mental health area, but it was not just for Caps. It provides tools and instruments to the worker of any equipment from UBS, CER or Caps - and by making use of them he can rethink his intervention. At least so you can reflect on what you do, and internalize to your style what you're learning. (Worker 2).

The working territory was the point of convergence between the view of teachers and that of students/workers, making unique the training process of each class, facilitating the collective characterization of vulnerabilities and main social determinations of psychological suffering, for the recognition of formal and informal resources available in the organization of care and in the presentation of innovative strategies and interventions capable of enhancing networking.

Courses were offered in independent modules, without there being sequential prerequisites among them. Organizing them in thematic areas intended to weave a thread between them, producing a sense of continuity from theoretical and conceptual references common to the psychosocial field.

\section{Building a theoretical- conceptual basis for validating psychosocial care}

The social constructionist perspective - the methodological basis of the research that sought to investigate the meanings of permanent education in the PRS - regards knowledge as a result of a social construction and not as a reflection of the observation of the world as it presents itself. According to Souza ${ }^{4}$, the actuality status of a given phenomenon is given by the criteria of legitimacy assumed by a community to be true.

As an interactive enterprise, the social practices in use by individuals constantly undergo movements of meaning and reframing that sometimes ratify them and sometimes rectify them. It is the 'production of meaning' what validates the knowledge built in the realm of the collective from defamiliarization movements with rituals assumed as obvious by social groups. Through positioning games in groups, agreements are formed that validate truths and legitimize knowledge ${ }^{5}$.

Validating psychosocial care across the Raps therefore implies discussing and questioning nursing home practices in use by professionals at all points of care and making a new fabric of meanings for care. As Rotelli6(43) states:

We must start from the assumption that in the world there are still millions of people inside psychiatric hospitals, that there are new forms of hospitalization through heavy pharmacological conditioning. There is a pharmacological confinement when, through medicines, we reduce a person's body to an inert body. There is a psychological confinement when we reduce the person to his illness. Against all these forms of confinement we have an infinite struggle yet to be fought and the strategy for fighting this struggle is through professionals who must acquire new knowledge, who must deepen 
their knowledge on this theme of the complexity of the relations of the social body.

Costa-Rosa7(144) analyzes the conceptions of the practices in mental health and sees two spheres which are inseparable yet different: the political-ideological sphere and the theoretical-technical one. As far as he sees,

it is possible to consider that two models of action in the field of mental health are alternative if they are contradictory. And two models will be contradictory if the essence of their practices goes in directions opposite to their basic parameters.

The author also points out that the rescue of dignity and citizenship addressed in the psychosocial model, which has been widely referenced by anti-asylum movements, belongs to the political-ideological dimension. However, it is of fundamental importance to elucidate the psychosocial paradigm also in its theoretical and technical aspects, thinking about the response modes built to face the approaches of what he called asylum model.

Amarante ${ }^{8(63)}$ stresses that mental health must be considered as a social process

of complexity [which] is made of the interlacing of simultaneous dimensions that, depending on the moment, feed from each other or are in conflict with one another; that give rise to pulsations, paradoxes, contradictions, consensus, tensions.

This conception refers to movement, to transformation, to a path in which paradigms are reaffirmed or where ruptures are structured and this leads to the understanding of insanity as a phenomenon requiring to outline the bases of psychosocial care in opposition to the asylum model. The author defines four dimensions inherent to this process: theoretical-conceptual, legal-political, technical-assistance wise and socio-cultural.

The 'theoretical-conceptual dimension' is the epistemological basis for the development of the field as a science. Basaglia, cited by Amarante ${ }^{8}$, highlights that psychiatry separates the fictitious object, the disease, from the global and complex existence of the individuals and of the social body, being it the disease, and not the individual who experiences it, the object of its scientific development. The psychosocial field aims to see 'the disease in parentheses' as a new possibility of producing knowledge based on its implication with the individual's experience, which does not mean denying the disease as a producer of suffering, but rather directing the epistemic focus to the individuals and their life trajectory, built by social, historical, cultural determinations that reaffirm multiple possibilities of being and living ${ }^{8}$.

The 'technical-assistance wise dimension' refers to spaces for the production of care, which should focus on analyzing everyday problems and intervening on them: personal and social relationships, work, leisure, housing. Assistance services are understood as "strategic devices, such as places for reception, care and social exchanges [...] places of sociability and production of individuality"8(69).

The 'legal-political dimension' is constituted as a field of strategic dispute in the construction of citizenship, being driven by social movements in the tensioning of government agendas and in the consolidation of legal frameworks and mechanisms that guarantee human rights.

Finally, the 'socio-cultural dimension' has as its horizon the constitution of a new project of society, a real possibility of social transformation, as it bases itself on the involvement of the whole society in the discussion about the insanity paradigm. The creation of cultural projects and collective living spaces makes a great contribution to the alteration of the social place of individuals in psychological distress. According to 
Basaglia, society's relationship with these individuals should not be based on feelings of tolerance, but on evoking meanings of reciprocity and solidarity 9 .

In order to cover all these dimensions, the short courses of the PRS were configured around four thematic areas, developing, in the period of analysis, nine short courses. Table 2 shows the areas, courses and the number of classes and of participating workers.

Table 2. Activities of the Rede Sampa Project - Saúde Mental Paulistana

\begin{tabular}{|c|c|c|c|}
\hline Theme area & Courses & $\begin{array}{l}\text { № of } \\
\text { classes }\end{array}$ & $\begin{array}{r}\text { № de } \\
\text { participants }\end{array}$ \\
\hline \multirow{2}{*}{$\begin{array}{l}\text { Childhood and } \\
\text { adolescese mental } \\
\text { healthcare }\end{array}$} & Family care & 28 & 822 \\
\hline & $\begin{array}{l}\text { Vulnerabilities and psychosocial risk situations during child- } \\
\text { hood and adolescence: approach and lines of integral care }\end{array}$ & 18 & 252 \\
\hline \multirow{2}{*}{$\begin{array}{l}\text { Adult mental healhcare } \\
\text { and crisis situations }\end{array}$} & Management and wider concept of mental health crisis & 20 & 496 \\
\hline & Psychopathology, Psychopharmacology and Medicalization & 18 & 514 \\
\hline \multirow[t]{2}{*}{$\begin{array}{l}\text { Healthcare of users } \\
\text { of Psychoactive } \\
\text { substances }\end{array}$} & $\begin{array}{l}\text { History and epidemiology of drug use: fron the reductionist } \\
\text { view of the disease to the Policy for Mental Healthcare, Alcohol } \\
\text { and orhter Drugs }\end{array}$ & 24 & 652 \\
\hline & $\begin{array}{l}\text { Harm reduction: concept, myths and action strategies in the } \\
\text { territory of the vulnerable population }\end{array}$ & 19 & 339 \\
\hline \multirow[t]{3}{*}{$\begin{array}{l}\text { Psychosocial care } \\
\text { network }\end{array}$} & $\begin{array}{l}\text { The SUS, the Psychiatric Reform and the challenges for } \\
\text { strengthening Psychosocial Care Network }\end{array}$ & 20 & 547 \\
\hline & Matrixation.* & 25 & 2.896 \\
\hline & Integral care lines and Singular Therapeutical Project.* & 22 & 2.435 \\
\hline Total & & 194 & 8.953 \\
\hline
\end{tabular}

\section{The pscychosocial} paradigma that permeates the work at the Raps: building senses at the PRS

The survey respondents reported that the project covered multiple dimensions of the process referred to by Amarante, based on the understanding of the social, historical, cultural determinations of psychological suffering and considering that the production of care must permeate a support network constituted in the interaction between sectors.

The area of 'Care to mental health in childhood and adolescence' discussed the themes of family care and the main territorial vulnerabilities in the first cycles of life, addressing psychological suffering based on social determinations and identifying the interface between the various social sectors in which users fit in.

It is not only an individual dimension, of psychological suffering: the idea of a suffering that also has causes, motives, in social traumas, in retraumatization, in the experiences of uprooting, migration [...] recognizing that psychological suffering is of high complexity. This cannot be read in an exclusively biochemical or moral interpretation. (Teacher 2). 
In the area of 'Care for adult mental health and crisis situations', the themes of crisis management and concept were addressed, along with those of psychopathology, psychopharmacology and medicalization. In the interviews, there is an understanding of insanity and psychological suffering as being part of the individual's existence. Based on that, there are multiple possibilities of care that present themselves as an alternative to framing life in pathology and medicalization processes. Reports of workers interviewed point out that these approaches had repercussions among the teams, even if the prevalent culture of services is focused on medicalization.

Is it possible to provide care to a patient without medication? This was a theme that led to much discussion in classroom, given that the teacher brought a few examples of international experiences: following up a user in a psychotic break without drug intervention [...]. This was also useful for us in this Caps reality to think about the users who do not accept drug intervention and who are in a crisis, and we try to work on the bond, on the care in a widened manner. (Worker 2).

In 'Health care for users of Psychoactive Substances', interventions focused on prohibitionist aspects were addressed, and harm reduction was introduced as a possibility of focusing on care based on respect for individual choices.

One thing we discussed a lot was the legalization of drugs. There were obviously people who were for and against, but we were asking what the possibilities would be if you could have another context. So no one was forcing anyone to change their mind, but how different would it be for the user to go to the Caps without any feeling of shame, or without fear because he was using crack. [...] Another thing that we discussed a lot was the drug as a business in our society, a business like any other, like the capitalist of the pharmaceutical industry. (Worker 2).
The debates promoted by teachers who worked in the 'Psychosocial Care Network' addressed the legal-political dimension, discussing the importance of health reform movements to the creation of SUS, the psychiatric reform and the Raps work model. In the 'Matrixing' and 'Care line' approach, there was a change in the work strategy, which led to a debate about the network in the territory, based on its determinations and potential, leading workers from different units to form collectives. This work methodology addressed the socio-cultural dimension, relying on content radically structured on the territorial reality, their formal, informal, active and capable of being activated networks, having as a background the theories that support psychosocial care.

What was present as a guiding axis was the construction of the network. There was no specific content... there was a much bigger variaton that depended on the territory [...] the network building idea that was on the basis of the relation with others, the relation between the equipment and the forms of care. (Teacher 2).

The dissemination of these discussions about the dimensions of psychosocial care for health unit workers of different complexities, especially for Primary Care teams, allowed us to focus on understanding the complaints, suffering and pains so common in the daily work of professionals.

In this sense, the training processes must enable not only the discussion about the individual approach to care, but also stimulate the debate about the multiple determinations of suffering and question the implication of their practices in the ways of producing public and collective health, in the reproduction of the processes of seeing only the pathology and the medicalization of life and of commodification of health. 


\section{Sistematyizing knowledge into collective narratives}

The objective of strengthening the Raps was guided by the stimulus to create for workers of different services a living network and connections that would expand the meeting opportunities, the establishment of commitments and the validation of new practices based on psychosocial care. Dialogic processes were considered strategies to generate meaning for the groups, since they allowed the reinterpretation of phenomena and reflection, summoning individuals to position themselves and enabling the institutionalization and socialization of new social practices ${ }^{2}$.

One of the positive effects of PRS was to put in direct contact individuals who would relate only institutionally. Machado, Guizardi and Lemos ${ }^{10(6)}$ warn about the fact that it is the relational dynamics the element that constitutes "networks of sociability in which institutional modes of operation are always unstable and singular". Respondents' reports highlighted this aspect, mentioning that the creation of new bonds led to improving the way network work is conducted.

There, in the classroom, we could see what is expected to happen outside the classroom: the network is organized and strengthened by a discussion, or by a concept that made them think. In that sense, people got connected, people who hadn't met before, services that did not know each other [...] this diversity has always been very powerful at Rede Sampa, and I think this needs to be sustained in all courses: from the ACS up to the doctors, all of them having a dialogue. (Teacher 2).

The training spaces constituted at the PRS aimed at expanding those sociability networks with a perspective of questioning the forms of care through a collective construction of knowledge, as remarked by a respondent:
The course had this power of calling to debate, to make people position themselves regarding different sources of knowledge and to recover the place of the individual being taken care of... allowing the professional to challenge his theoretical and ideological references, so he can see the person being provided care from another angle. (Teacher 2).

Recognizing social interaction as a space for legitimizing knowledge implies considering dialogic processes as articulators of positioning games in groups that give meaning to human experiences and support social practices ${ }^{5}$. Language is understood here not as a system of representation of facts and phenomena, but as a human activity that produces reality in itself, that produces truth.

Thus, the elaboration of a text, named 'collective narrative', was the process of systematization of the knowledge common to the classes attending the courses given, allowing professionals who participated in the PRS to register the dialogical mediation taking place between contents and references developed in the courses, the work territory and care practices developed there. The opening of this narrative space allows the reconstruction of experiences in a reflexive way, the understanding of their doing, of their being in the world, in a theorization of their own experience ${ }^{11}$.

Constituted in the semi-in person modality, the short courses of the PRS had in their in person classes an encounter environment and a constitution of dialogicity. AVA has established itself as a resource with low task requirements, being seen as a virtual repository of videos, slides, films, articles, links and bibliographic references. In short, all didactic-pedagogical material. Also in the AVA, 'collective narratives' were developed.

The Wiki tool, available on the Moodle ${ }^{\circledR}$ Platform, is aimed at building collaborative works. From questions addressed in the faceto-face class, triggering questions were placed on the platform so that the participants could write their personal reflections, in view of an approximation between the content of the 
class and the work experience. Built during the course, these records enabled the final elaboration of a Narrative alluding to the characterization of the main territorial vulnerabilities, available resources, recognition of formal and informal partners in the effectiveness of care, presentation of interventions built by workers and communities, giving outline and materiality to the knowledge common to that group.

Going beyond the execution of the proposed task of registering the work, we could observe that the Narratives were constituted as an expanded teaching-learning space, since they entered the classroom space and proved to be a tool for the teacher's work, producing reflection on the instituted praxis and enabling new ways of thinking about care ${ }^{\mathbf{2}}$.

\section{Conclusions}

The PRS was developed based on a variety of actions, bringing together heterogeneous groups of workers from different levels of care. Taking as a reference the guidelines established by PNEPS, it developed actions in transdisciplinary approaches, based on the learning needs identified by workers in their daily work.

From the pedagogical point of view, the elaboration of classes carried out in an open and procedural way produced movements of co-authorship between coordinators and teachers, facilitated the permeability of the curriculum to the practices of professionals and the singularities of territorial networks and established spaces for reception, listening and exchange for the group of trainers.

The mental health field, due to the characteristic of questioning about the social normativity that constitutes the psychosocial or asylum paradigms, involves debates that present, on the one hand, possibilities of welcoming plural forms of living, the right to freedom, expansion of social contractuality and, on the other, institutionalization, segregation or social isolation and the invalidation of individualive productions. Discussions about mental health care paradigms are not always present in the trajectories of primary care workers, either working in hospital units or in a specialization, and this points to the need to discuss the care model that underlies the work practices in these services. Issues such as the use of psychoactive substances, medicalization and pathologization of life carry a great deal of stigma and prejudice, even among health professionals.

Thus, from the point of view of strengthening psychosocial care through the different points of care in the network, the actions developed enabled workers to recognize partners in their work territory, to present common problems, to develop joint referrals and new aligned strategies to the psychosocial model considering, beyond the biological determinants, the approach of social, economic, cultural, affective determinations of psychological suffering.

Materializing the importance given to the knowledge built in the daily lives of the territories, the collective narratives made the theory/practice interface, configuring themselves as a possibility of extending the space of the classrooms, as well as of presenting care, respect and valuation of the knowledge built in the daily life by the network professionals.

The training of workers in EPS processes with a focus on the needs of health teams can be diversified and favor the articulation of different points of care based on teaching methodologies that consider professional heterogeneity, the diverse nature of services and the territorial singularities. These formative processes allow the groups to understand phenomena, give meaning to experiences, constitute common references and validate the knowledge produced in the group environment in spaces of mobilization, knowledge sharing and establishment of new social practices. 


\section{Collaborators}

Authors performed different tasks: Costa CM (0000-0001-8105-995X)* contributed to the conception, planning, analysis and interpretation of data. Abreu CRM
(0000-0003-0654-663X)* contributed to approving the final version of the manuscript. Amarante P (0000-0001-6778-2834)* and Machado FRS (0000-0002-5028-8888)* contributed to the critical review and final approval of the manuscript.

\section{References}

1. Brasil. Ministério da Saúde. Portaria n ${ }^{0} 3.088$, de 23 de dezembro de 2011. Institui a Rede de Atenção Psicossocial para pessoas com sofrimento ou transtorno mental e com necessidades decorrentes do uso de crack, álcool e outras drogas, no âmbito do Sistema Único de Saúde (SUS). Diário Oficial da União [internet]. 24 Dez 2011 [acesso em 2021 jan 19]. Disponível em: http://bvsms.saude.gov.br/bvs/saudelegis/ gm/2011/prt3088_23_12_2011_rep.html.

2. Costa CM. Os sentidos da educação permanente em saúde para o trabalho em rede: análise de uma experiência na Rede Psicossocial do município de São Paulo [dissertação]. [Rio de Janeiro]: Fundação Oswaldo Cruz; 2019. 100 p.

3 formação para a área da saúde: ensino, gestão, atenção e controle social. Physis. 2004; 14(1):41-65.

*Orcid (Open Researcher and Contributor ID).
4. Souza L. Discurso construcionista social: uma apresentação possível. In: Guanaes C, Moscheta M, Corra-
di-Webster C, et al., organizadores. Construcionismo social: discurso, prática e produção do conhecimento. Rio de Janeiro: Instituto Noos; 2014. p. 49-7.

5. Spink MJ. Práticas discursivas e produção de sentidos no cotidiano. Rio de Janeiro: Centro Edelstein de Pesquisas Sociais; 2013.

6. Rotelli F. Formação e construção de novas instituições em saúde mental. In: Amarante P, Cruz LB, organizadores. Saúde Mental, formação e crítica. Rio de Janeiro: Fiocruz; 2015. p. 37-50.

7. Costa-Rosa A. O modo psicossocial: um paradigma das práticas substitutivas ao modo asilar. In: Amarante P, organizador. Ensaios: subjetividade, saúde mental, sociedade. Rio de Janeiro: Fiocruz; 2000. p. 141-168.

8. Amarante P. Saúde mental e atenção psicossocial. 4. ed. Rio de Janeiro: Fiocruz; 2013. p. 62-81. 
9. Basaglia F. Saúde/doença. In: Amarante P, Cruz LB, organizadores. Saúde Mental, formação e crítica. Rio de Janeiro: Fiocruz; 2015. p. 17-36.

10. Machado FRS, Guizardi FL, Lemos ASP. A burocracia cordial: a implantação da estratégia de apoio institucional na política nacional de atenção básica em saúde. Trab. educ. saúde. 2019; 17(3):1-26.

11. Cunha MI. Conta-me agora! As narrativas como al- ternativas pedagógicas na pesquisa e no ensino. Rev.

Fac. Educ. 1997; 23(1-2):185-195.

12. Abreu CRGM. A narrativa como estratégia de formação na educação em saúde [dissertação]. [Rio de Janeiro]: Fundação Oswaldo Cruz; 2019. 110 p.

Received on $11 / 13 / 2019$

Approved on 18/09/2020

Conflict of interests: non-existent

Financial support: non-existent 